\title{
Ferritin, Fibrinojen ve Prokalsitonin Düzeyleri Gebelerde COVID-19 Klinik Seyrini Nasıl Etkiler?
}

How Do Levels of Ferritin, Fibrinogen and Procalcitonin Affect the Clinical Course of COVID-19 in Pregnant Women?

\author{
Huri Güvey ${ }^{1}$, Canan Soyer Çalışkan², Samettin Çelik², Merve Yılmaz ${ }^{3}$, Zehra Yılmaz \\ ${ }^{1}$ Özel Parkhayat Kütahya Hastanesi Kütahya/Türkiye \\ ${ }^{2}$ Samsun Eğitim ve Araştırma Hastanesi Kadın Hastalıkları ve Doğum Bölümü Samsun/TÜRKIYYE \\ ${ }^{3}$ Samsun Gazi Devlet Hastanesi Endokrinoloji ve Metabolizma Hastalıları Bölümü Samsun/TÜRKIYYE \\ ${ }^{4}$ Denizevler mahallesi Alaçam caddesi No:8 Tema ofis Atakum/Samsun/TÜRKIYYE
}

\author{
Yazı̧sma Adresi / Correspondence: \\ Huri Güvey \\ Dumlupınar mahallesi Şehit Er Bahtiyar Yalınca Caddesi Numara 15/8 Merkez/Kütahya TÜRKIYE \\ T: +905335655358 E-mail : huriguvey@gmail.com \\ Geliş Tarihi / Received : 03.05.2021 Kabul Tarihi/ Accepte: 11.12.2021 \\ Orcid : \\ Huri Güvey https://orcid.org/0000-0002-8603-6981 \\ Canan Soyer Çalışkan https://orcid.org/0000-0002-9889-5249 \\ Samettin Çelik https://orcid.org/0000-0002-6407-1129 \\ Merve Yllmaz https://orcid.org/0000-0002-3421-8548 \\ Zehra Yılmaz https://orcid.org/0000-0003-1162-8648 \\ ( Sakarya Tip Dergisi / Sakarya Med J 2021, 11(4):940-946 ) DOI: 10.31832/smj.932304
}

\footnotetext{
Öz

Amaç Coronavirus Disease 2019 (COVID-19) birçok insanı olduğu kadar gebeleri de etkileyen bir pandemidir. Çalışmamızın amacı inflamatuar belirteçlerin gebelerde COVID-19 seyrine etkisini araștırmaktır.

Yöntem ve Severe acute respiratory syndrome coronavirus 2 (SARS-CoV-2) pozitif olan 125 ve negatif olan 40 gebenin dahil edildiği bu kesitsel tipe tanımlayıcı çalışmada, COVID-19

Gereçler olan hastalar oksijen satürasyonu, akciğer tutulumu bulgularına göre hafif orta ve ağır olarak gruplandırılmıștır. Fibirnojen, ferritin ve prokalsitonin değerleri karşılaștırilmıștır.

Bulgular SARS-CoV-2 durumuna göre gebelerin ferritin $(\mathrm{p}=0,241)$ ve prokalsitonin $(\mathrm{p}=0,579)$ değerleri arasında da anlamlı fark saptanmazken, testi pozitif gebelerin fibrinojen değerleri anlamlı olarak yüksek bulunmuștur $(\mathrm{p}<0,001)$. SARS-CoV-2 pozitif olan katılımcıları kendi içerisinde klinik durumuna hafif, orta ve ağır olarak gruplandırıp baktığımızda ise; fibrinojen $(\mathrm{p}<0,001)$ değerleri arasında anlamlı fark saptanmıştır. İkili karşılaștırmada klinik seyri hafif olan grupta fibrinojen değeri orta ( $<<0,001)$ ve ağır $(\mathrm{p}<0,001)$ olan gruptan, klinik seyri orta olan grubun fibrinojen değeri ise ağır olan gruptan anlamlı olarak düșük saptanmıștır $(\mathrm{p}=0,007)$

Sonuç Hastalığın ağırlığı arttıkça fibrinojen seviyelerinin de arttığını tespit ettik. Fibrinojen gebelerde COVID-19 klinik durumunun ağırlı̆̆ı ile ilgili bir gösterge olabilir ancak bu bulguyu güçlendirmek için daha büyük örnekleme sahip prospektif, izleme dayalı çalıșmalar gerekmektedir.

Anahtar

Kelimeler

COVID-19; gebelik; ferritin; fibrinojen; prokalsitonin

\begin{abstract}
Introduction Coronavirus disease 2019 (COVID 19) is a pandemic affecting pregnant women as well as lots of people. The aim of our study is to investigate the effects of inflammatory markers on the course of COVID-19 in pregnant women.

Materials : In this cross-sectional descriptive study, which included 125 pregnant women who were positive for Severe acute respiratory syndrome coronavirus 2 (SARS-CoV-2) and 40 and Methods women who were negative, patients with COVID-19 were grouped as mild, moderate and severe according to oxygen saturation, lung involvement findings. Fibrinogen, ferritin and procalcitonin values of the participants were compared.

Results While there was no significant difference between the ferritin $(p=0,241)$ and, procalcitonin $(p=0,579)$ values of pregnant women according to the SARS-CoV-2 status, the fibrinogen values of pregnant women with positive test were found to be significantly higher $(p<0,001)$. When we categorize the participants who are positive for SARS-CoV-2 as mild, moderate and severe; a significant difference was found between fibrinogen $(p<0,001)$ values. In paired comparison, the fibrinogen value of the group with mild disease was found to be significantly lower than the group with moderate $(p<0,001)$ and, severe $(p<0,001)$, and the group with a moderate disease compared to the group with severe
\end{abstract} $(p=0,007)$.

Conclusion We found that as the severity of the disease increased, fibrinogen levels also increased. Fibrinogen may be an indicator of the severity of the COVID-19 clinical course in pregnant women, but prospective, follow-up studies with larger samples are required to reinforce this finding.

Keywords COVID-19; pregnancy; fibrinogen; ferritin; procalcitonin
} 


\section{GIIRIŞ}

Aralık 2019'da Çin'in Wuhan kentinde ortaya ortaya çıkan yeni koronavirüs infeksiyonu hızlı bir şekilde tüm dünyaya yayılarak pandemiye dönüştü. Dünya Sağlık Örgütü tarafından Coronavirus Disease 2019 (COVID-19) olarak adlandırılan hastalık ateş, halsizlik,öksürük, kas ağrısı ve nefes darlığı gibi belirtilerle ortaya çıkmakta ve ağır pnömoniye sebep olabilmektedir. ${ }^{1}$ Hastalığın etkeni olarak izole edilen ribonükleik asit (RNA) virüsü reverse transkriptaz polimeraz zincir reaksiyonu (RT-PCR) yöntemiyle tespit edildi ve severe acute respiratory syndrome coronavirus 2 (SARS-CoV-2) olarak adlandırıldı. ${ }^{2}$ Gebelikte ortaya çıkan fizyolojik değişiklikler ve baskılanmış bağışıklık sistemi viral pnömonilere yatkınlığ artırabilmektedir. $^{3}$ Literatürdeki çalışmalarda gebelikte COVID-19'un normal popülasyondan daha ağır seyretmediği ancak nadir de olsa maternal mortalite ve perinatal komplikasyon sebebi de olabildiği belirtilmiştir. ${ }^{4}$

Fibrinojen akut faz reaktanlarından biri olup interlökin (IL)-1 ve IL-6 salınımına cevaben karaciğerden üretilir. Ayrıca tetiklenen pıhtılaşma yolağında son basamak olan fibrin oluşumda görev alır. Ayrıca dissemine intravasküler koagülasyon (DIC) tanısında skorlama parametrelerinden biri olarak fibrinojen seviyerinin de kullanıldığı gösterilmiştir. ${ }^{5}$ COVID-19 ve DIC'in yakın ilişkisi nedeniyle pandemi döneminde araştırma konusu olmuştur. Örneğin bir İtalyan çalışmasında acil servise ateş ve nefes darlığı şikayetiyle başvuran hastalar değerlendirildiğinde COVID-19 tanısı alan ve akut respiratuvar distres sendromu gelişen hastalarda fibrinojen seviyeleri anlamlı olarak yüksek bulunmuştur. ${ }^{6}$

Prokalsitonin tiroidin parafoliküler C hücrelerinden kalsitonin hormonunun öncülü olarak sentezlenir. Ayrıca bakteriyel infeksiyon sirasında tümör nekrozis faktör alfa (TNFa) ve IL-6 etkisiyle tiroid dışı dokulardan da salg1lanır. Antibiyotik tedavisi sonucu da artan prokalsitonin seviyelerinde düşme gözlenir. ${ }^{7}$
Ferritin demir depolayan bir proteindir ve transpost sürecinde yer almaz. Genellikle vücuttaki demir durumunu öğrenmek için kullanılır. ${ }^{8}$ İnflamatuar süreçlerde IL-1,6 ve interferon gama (IFN $\gamma)$ karaciğer ve makrofajlardan ferritin üretimini artırır. Ferritin de hücre içi inflamatuar yolakları aktive eder. Ayrıca inflamasyon sonucu oluşan hücre hasarı sonrası açığa çıkan ferritin, kan düzeylerinde artışa neden olur. ${ }^{9}$ Araştırmalarda kliniği ağır seyreden COVID-19 vakalarında ferritin seviyeleri anlamlı olarak yüksek saptanmıştır. ${ }^{10}$

COVID-19 klinik seyrine etki eden faktörleri belirlemek takip ve tedavi protokollerini yönetme açısından oldukça önemlidir. Gebelikte COVID-19 yönetiminde normal popülasyondan farklı olarak hem anne hem fetüsün hayatta kalabilmesini sağlamak ve gebelikte değişen fizyolojiyi de göz önüne alarak hareket etmek gerekir. Gebe olmayan popülasyonla kıyaslandığında gebe popülasyonda ciddi COVID- 19 enfeksiyonu geçirme olasılığ artmıştır. $^{11} \mathrm{Bu}$ nedenle gebelikte klinik seyri etkileyebilecek inflamatuar belirteçleri saptamak önem arz etmektedir. Literatürde gebe olmayan popülasyonda konuyla ilgili çalışmalar olmasına rağmen gebelikteki durumla ilgili çalışma oldukça azdır. Amacımız gebelerde ferritin, fibrinojen ve prokalsitonin gibi inflamatuar belirteçlerin COVID-19 klinik seyrine etkisini incelemektir.

\section{GEREÇ ve YÖNTEMLER}

Çalışma epidemiyolojik açıdan kesitsel olarak tanımlayıcı nitelikte dizayn edilmiş olup hastaların verilerine retrospektif olarak hastane otomasyon veri tabanı kullanılarak ulaşılmıştır. Araştırmaya Mart 2020 ve Ocak 2021 tarihleri arasında Samsun Eğitim ve Araştırma Hastanesi'ne baş ağrısı, öksürük, nefes darlığı, ishal ateş, tat kaybı, miyalji gibi COVID-19 semptomlarından bir veya birkaçı ile başvuran 182 gebe dahil edilmiştir. Gebelerden nazofarengeal ve orofarengeal sürüntü örneği alınarak RT-PCR yöntemiyle SARS-CoV-2 varlığı hastanenin merkez laboratuvarında araştırılmış ve gebeler hastaneye yatırılmıştır. RT-PCR sonucu pozitif çıkan gebeler çalışma grubuna alınırken ne- 
gatif çıkanlar kontrol grubuna alınmıştır. Sonucu negatif gelen hastalar şikayetlerinde artış olmadığı teyit edildikten sonra taburcu edilmiş ve takiplerinde herhangi bir problem bildirmemişlerdir. RT-PCR sonucu pozitif olan hastalar ise klinik durumuna göre yatırılarak veya ayakta takip ve tedavisine devam edilmiştir. Tanı konulmuş herhangi bir pıhtılaşma bozukluğu olan ( $n=2)$ ve COVID-19 dışında infeksiyonu olan $(n=7)$ ve herhangi bir ilaç tedavisi alan $(n=8)$ gebeler çalışmaya dahil edilmemiştir. SARS-CoV-2 pozitif hastaların klinik sınıflandırması ise şu şekilde yapıldı: oksijen satürasyonu $\% 94$ ve üzeri olup akciğer tutulumu yoksa hafif, oksijen satürasyonu \%94 ün altında ve ön arka akciğer grafisinde \% 50'den az alanda akciğer tutulumu varsa orta, oksijen satürasyonu \%94 ün altında ve ön arka akciğer grafisinde \% 50'den fazla alanda akciğer tutulumu varsa ağır olarak gruplandırıldı. ${ }^{12}$ Çalışmanın yürütüldüğü hastanede çalışmanın yapıldığı tarihe kadar mekanik ventilasyon ihtiyacı olan veya ölen hasta olmamıştır. Çalışma yapıldı̆̆ı sırada katılımcılardan hastanede tedavisi devam eden bulunmamaktaydı. Katılımcıların gebelik haftası son adet tarihinin ilk gününe göre veya ilk trimester ultasonografisine göre hesaplandı. Prokalsitonin değerlerndirmesi için katılımcılardan alınan venöz kan örneği Abbott Architect i2000 immuno-analyser (Abbott Laboratories Ltd, Maidenhead, UK) cihazıyla kemiilluminesans yöntemi kullanılarak ölçüldü. Fibrinojen seviyeleri venöz sitratlı kan örneğinden fonksiyonel pıhtılaşma analiziyle IL CoagulationSystem ${ }^{\circledast}$ (Instrumentation Laboratory, Bedford, MA, USA) cihazı kullanılarak ölçüldü. Ferritin seviyeleri ise venöz kan örneği Cobas C501 Analyzer (Roche Diagnostics, Rotkreuz, Switzerland) cihazında analiz edilerek saptandı. Hastaların başvuru esnasındaki değerleri baz alındı. Araştırmanın yapılması için Helsinki Deklerasyonu kriterleri gözetilmiş olup Samsun Eğitim ve Araştırma Hastanesi Girişimsel Olmayan Klinik Araştırmalar Etik Kurulunun 13.01.2021 tarih ve 2021/1/16 sayılı etik kurul onayı gözetilmiştir.

Verilerin analizi SPSS 25 (Statistical Package for Social Sciences) paket programında yapıldı. Tanımlayıcı istatis- tikler sayısal değişkenler için ortalama \pm standart sapma ve ortanca (minimum-maximum) olarak gösterildi. Sayısal değişkenlerin dağılımının normale uygun olup olmadığ Kolmogorov Smirnov testi ve Shapiro-Wilks testi ile araştırıldı. Gruplar arasında normal dağılmayan sayısal değişkenler yönünden istatistiksel olarak anlamlı bir farkın olup olmadığı Mann-Whitney U testi ve Kruskal-Wallis testi ile değerlendirildi. $\mathrm{p}<0,05$ için sonuçlar istatistiksel olarak anlamlı kabul edildi. Kruskal-Wallis testi ile anlamlı bulunan değişkenlerde anlamlılığın nereden kaynaklandığını bulmak için Bonferroni düzeltmeli Mann-Whitney U testi yapıldı ve $\mathrm{p}<0,017$ olanlar anlamlı kabul edildi.

\section{BULGULAR}

Toplam 165 gebe çalışmaya dahil edilmiştir. Tablo 1 ve Şekil 1'de belirtildiği üzere, SARS-CoV-2 açısından negatif olan 40 gebenin yaşları 19 ve 39 arasında, SARS-CoV-2 açısından pozitif olan 125 gebenin ise yaşları 18 ile 44 arasında değişmektedir ve SARS-CoV-2 pozitif 125 gebenin median yaşı negatif olanlara göre istatistiksel açıdan anlamlı olarak daha büyüktür ( $\mathrm{p}=0,005)$. Grupların gebelik haftası $(p=0,073)$ ve sayısı $(p=0,092)$ arasında anlamlı fark bulunmazken, SARS-CoV-2 testi pozitif olan gebelerin hastanede yatış süresi daha uzundur $(\mathrm{p}<0,001)$. Ayrıca grupların ferritin $(\mathrm{p}=0,241)$ ve prokalsitonin $(\mathrm{p}=0,579)$ değerleri arasında da anlamlı fark saptanmazken, SARSCoV-2 testi pozitif gebelerin fibrinojen değerleri anlamlı olarak yüksek bulunmuştur $(\mathrm{p}<0,001)$.

SARS-CoV-2 pozitif olan gebeleri kendi içerisinde klinik durumuna hafif $(n=73)$, orta $(n=38)$ ve ağır $(n=14)$ olarak gruplandırıp baktığımızda ise; grupların yaş $(\mathrm{p}=0,084)$, gebelik sayısı $(\mathrm{p}=0.613)$, hastanede yatış süresi $(\mathrm{p}=0,530)$, ferritin $(p=0,126)$ ve prokalsitonin $(p=0,189)$ değerleri arsında fark bulunmazken, gebelik haftası $(p=0,002)$ ve fibrinojen $(p<0,001)$ değerleri arasında anlamlı fark saptanmıştır (Tablo 2 ve Şekil 2). 
Sakarya Tip Dergisi 2021;11(4):940-946

GÜVEY ve Ark., İnflamatuar Belirteçler ve Gebelerde COVID-19

\begin{tabular}{|l|c|c|c|}
\hline Tablo 1. SARS-CoV-2 durumuna göre değişkenlerin karşılaştırılması & \multicolumn{1}{l|}{} \\
\hline Değişkenler & $\begin{array}{c}\text { SARS-CoV-2 negatif } \\
(\mathbf{n}=\mathbf{4 0})\end{array}$ & $\begin{array}{c}\text { SARS-CoV-2 pozitif } \\
(\mathbf{n = 1 2 5})\end{array}$ & $\mathbf{p}$ \\
\hline Yaş (yıl) & $26(19-39)$ & $31(18-44)$ & $\mathbf{0 , 0 0 5}$ \\
\hline Gebelik haftası & $28(5-41)$ & $32(5-41)$ & 0,073 \\
\hline Gebelik sayısı & $1,50(1-4)$ & $2(1-5)$ & 0,092 \\
\hline Hastanede yatış süresi (gün) & $3(1-9)$ & $6(1-16)$ & $<\mathbf{0 , 0 0 1}$ \\
\hline Ferritin $(\boldsymbol{\mu g} / \mathbf{L})$ & $31,50(5-211)$ & $33(5,47-390)$ & 0,241 \\
\hline Prokalsitonin $(\boldsymbol{\mu g} / \mathbf{L})$ & $0,054(0,002-0,17)$ & $0,055(0,002-0,223)$ & 0,579 \\
\hline Fibrinojen $(\mathbf{m g} / \mathbf{d L})$ & $356(135-768)$ & $454(229-990)$ & $<\mathbf{0 , 0 0 1}$ \\
\hline Değerler minimum-maksimum (median) olarak verilmiştir. & & \\
\hline
\end{tabular}

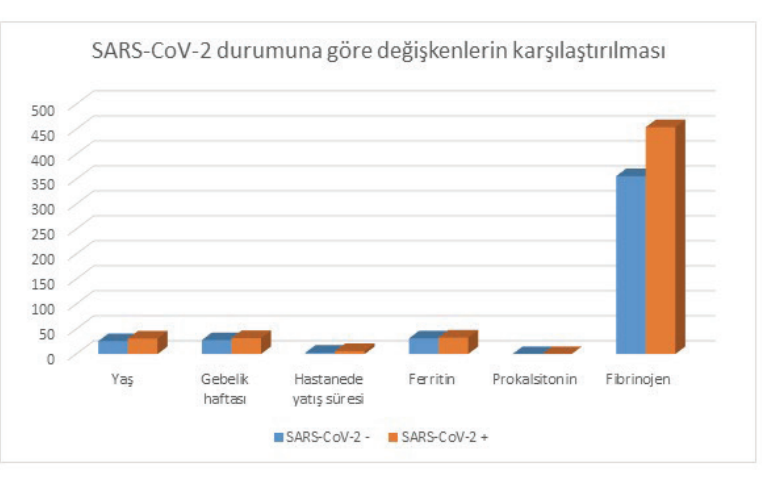

Şekil 1. SARS-CoV-2 durumuna göre değişkenlerin karșılaștırılması

\begin{tabular}{|l|c|c|c|c|}
\hline \multicolumn{5}{|l|}{ Hastalığın derecesine göre değişkenlerin karşılaştırılması } \\
\hline Değişkenler & Hafif $(\mathbf{n}=\mathbf{7 3})$ & Orta (n=38) & Ağır (n=14) & $\mathbf{p}$ \\
\hline Yaş (yıl) & $31(18-44)$ & $28(18-40)$ & $31,50(26-40)$ & 0,084 \\
\hline Gebelik haftası & $27(5-40)$ & $37(14-40)$ & $32(8-41)$ & $\mathbf{0 , 0 0 2}$ \\
\hline Gebelik sayısı & $2(1-4)$ & $2(1-5)$ & $2(1-3)$ & 0,613 \\
\hline Hastanede yatış süresi (gün) & $6(1-13)$ & $6,5(1-16)$ & $5(1-13)$ & 0,530 \\
\hline Ferritin $(\boldsymbol{\mu g} / \mathbf{L})$ & $33(9-311)$ & $29,5(5,47-155)$ & $45,11(19-390)$ & 0,126 \\
\hline Prokalsitonin $(\boldsymbol{\mu g} / \mathbf{L})$ & $0,055(0,002-0,099)$ & $0,053(0,023-0,223)$ & $0,065(0,023-0,099)$ & 0,189 \\
\hline Fibrinojen $(\mathbf{m g} / \mathbf{d L})$ & $422(229-789)$ & $542(263-890)$ & $779,5(443-990)$ & $<\mathbf{0 , 0 0 1}$ \\
\hline Değerler minimum-maksimum (median) olarak verilmiştir. & & & \\
\hline
\end{tabular}

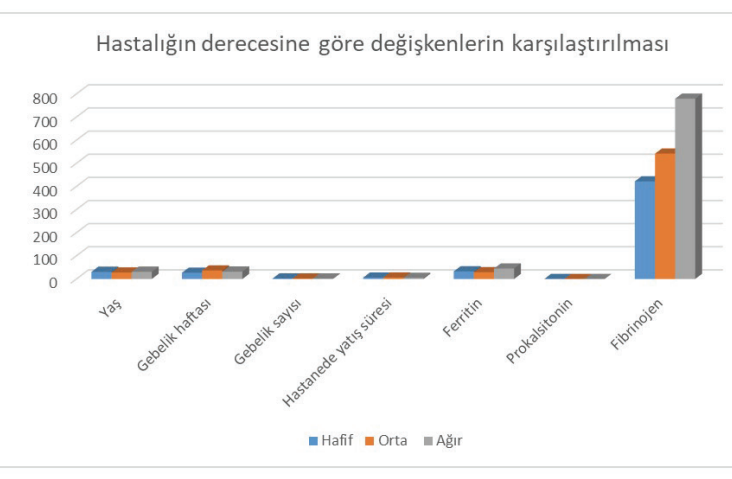


İkili karşılaştırmalarda klinik seyri hafif olan grupta orta olan gruba göre gebelik haftası anlamlı olarak küçükken $(\mathrm{p}=0,001)$, diğer gruplar arasında anlamlı fark gözlenmemiştir ( $\mathrm{p}=0,432$ ve $\mathrm{p}=0,056$ ). Klinik seyri hafif olan grupta fibrinojen değeri orta $(\mathrm{p}<0,001)$ ve ağır $(\mathrm{p}<0,001)$ olan gruptan, klinik seyri orta olan grubun fibrinojen değeri ise ağır olan gruptan anlamlı olarak düşük saptanmıştır $(\mathrm{p}=0,007)$ (Tablo 3).

\begin{tabular}{|l|c|c|c|}
\hline \multicolumn{2}{|l|}{$\begin{array}{l}\text { Tablo 3. Hastalığın derecesine göre farklılık saptanan parametre- } \\
\text { lerin karşılaştırılması }\end{array}$} \\
\hline & Hafif-orta & Hafif-ağır & Orta-ağır \\
\hline Değişkenler & $\mathbf{0 , 0 0 1}$ & 0,432 & 0,056 \\
\hline Gebelik haftası & $<\mathbf{0 , 0 0 1}$ & $<\mathbf{0 , 0 0 1}$ & $\mathbf{0 , 0 0 7}$ \\
\hline Fibrinojen (mg/dL) & & & \\
\hline
\end{tabular}

\section{TARTIŞMA}

Çalışmamızda COVID-19 semptomlarıyla başvuran ve RT-PCR testi yapılan gebeleri inceledik. Fibrinojen seviyelerini SARS-CoV-2 pozitif hastalarda daha yüksek olarak saptadık. Ayrıca hastalığın ağırlığı arttıkça fibrinojen seviyelerinin de arttığını saptadık. Ferritin ve prokalsitonin düzeylerinin ise gruplar arasında anlamlı farklılık göstermediğini tespit ettik.

Bi ve arkadaşlarının yürüttüğü 113 COVID-19 olan hastanın retrospektif analizine dayanan çalışmada bizim sonuçlarımıza paralel olarak klinik seyri ağır olan grupta fibrinojen seviyeleri ağır olmayanlara göre anlamlı olarak yüksek saptanmıştır. 13 Wuhan'da yürütülen bir çalışmada ise 94 COVID-19 hastası ve 40 sağlıklı bireyden oluşan kontrol grubu değerlendirilmiş ve COVID-19 olan grubun fibrinojen değerlerinin sağlıklı kontrollere göre daha yüksek olduğu saptanmıştır. ${ }^{14}$ Fibrinojen pıhtılaşma mekanizmasında önemli rol oynamaktadır. Enfeksiyöz hastalıklarda doğal bağışıklık yanıtının ilk aşamasında pıhtılaşma sistemi devreye girerek dokuda kan akımını yavaşlatır. İkinci aşamasında ise yavaşlamış kan akımı sayesinde damardan dışarı çıkarak dokuya göç eden nötrofiller, lenfositler ve lokal makrofajlar devreye girer. ${ }^{15}$ Ayrıca nötrofil ve monositlerde doku faktörü eksprese edilmektedir ve bu da pıhtılaşma yolağının tetiğini çekmektedir. Yani inflamatuar ve hemostatik mekanizmalar birlikte çalışmaktadır. ${ }^{16}$ COVID-19 infeksiyonunda literatürle uyumlu olarak bizim sonuçlarımızda da SARS-CoV-2 pozitif hastalarda ve klinik seyri ağır olan hastalarda fibrinojen seviyelerinin yüksek bulunması bu mekanizma ile açıklanabilir.

Çalışmamızın sonuçlarında COVID-19 tanısı doğrulanan hastalar ve PCR testi negatif olan grup arasında ve klinik seyri faklı gruplar arasında prokalsitonin seviyeleri açısından anlamlı bir fark tespit edilmemiştir. Literatürde bizim çalışmamızdan faklı sonuçlara ulaşan çalışmalar mevcuttur. ${ }^{17}$ Çin'de COVID-19 tanısı almış 1099 hastayla yapılmış bir çalışmada klinik seyri hafif olan ve kötü gidişatı olmayan hastaların 596'sında prokalsitonin seviyelerinin $0,5 \mu \mathrm{g} /$ L'nin altında olduğu gösterilmiştir. ${ }^{18}$ Yapılan

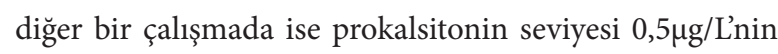
üzerinde olan COVID-19 hastalarının prokalsitonin seviyesi daha düşük olanlara göre ciddi infeksiyon riskinin 5 kat fazla olduğu belirtilmiştir. ${ }^{19}$ Prokalsitonin seviyeleri COVID-19'un ağırlı̆̆ını predikte etmenin yanı sıra eşlik eden bakteriyel infeksiyonun varlığını da gösterebilmektedir. COVID-19 hastalarında başlangıçta C-reaktif protein (CRP) seviyeleri yüksek iken, prokalsitonin seviyeleri normal sınırlarda seyreder. Ancak hastalık ağırlaşıp bakteriyel infeksiyon eşlik ettiğinde prokalsitonin seviyesi de

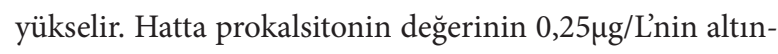
da olmasının bakteriyel infeksiyonu ekarte ettirebileceği öne sürülmüştür. ${ }^{20}$ Çalışmamızda hasta popülasyonunu seçerken eşlik eden herhangi bir infeksiyonu olan gebeler çalışmaya dahil edilmemiştir. Yani bakteriyel ko enfenksiyon varlığı en düşük seviyede tutulmaya çalışılmıştır. Bu sebeple gruplar arasında prokalsitonin seviyelerinin fark olmaması beklenen bir sonuçtur.

Çalışmamızın sonuçlarında COVID-19 tanısı doğrulanan hastalar ve PCR testi negatif olan grup arasında ve klinik seyri faklı gruplar arasında ferritin seviyeleri açısından anlamlı bir fark tespit edilmemiştir. COVID-19 olan gebelerde ferritin düzeyleriyle ilgili çalışmalar vaka seriyle 
sınırlıdır. Liu ve arkadaşlarının rapor ettiği vaka serisinde son trimesterde olan SARS-CoV-2 pozitif gebelerin hiçbirinde ferritin yüksekliği saptanmamıștır. ${ }^{21}$ Banchini ve arkadaşlarının 17 SARS-CoV-2 pozitif ve 30 akut cerrahi hastalık ile acil servise başvuran hasta üzerinde yürüttüğü bir çalışmada SARS-CoV-2 pozitif hastaların ferritin değerleri lökositozu bile olsa akut cerrahi hastalığ́ olan gruptan anlamlı olarak yüksek saptanmıştır. ${ }^{22}$ İsrail'de hastaneye COVID-19 nedeniyle yatışı yapılan 39 hastanın değerlendirildiği bir çalışmada, klinik durumu orta ve ağır olan grubun ferritin seviyeleri hafif olanlara göre, ağır olan grubun ise orta olan gruba göre anlamlı düzeyde yüksek olarak saptanmıştır ${ }^{10}$. Yapılan bu çalışmaların sonuçları örneklem sayısındaki kısıtlılık göz önünde bulundurularak yorumlanmalıdır. Örneklem azlığının nedeni olarak da çalışmaların retrospektif olması ve demir parametrelerinin COVID-19 hastalarında yaygın olarak kullanılmaması gösterilebilir. Cheng ve arkadaşlarının yaptığı bir meta analizde klinik seyri ağır olan hastalarda, ölüm vakalarında, bir veya daha fazla komorbiditesi olan hastalarda, yoğun bakım ve mekanik ventilasyon ihtiyacı olan hasta gruplarında ferritin düzeyinin anlamlı olarak yüksek bulunduğu rapor edilmiştir. ${ }^{23}$ Çalışmalarda klinik seyri ağır olan, mekanik ventilasyon ve yoğun bakım ihtiyacı olan COVID-19 hastalarında ferritin yüksekliğinin sebebi olarak sitokin firtınası sonucu gelişen hiperinflamamsyon ve buna bağlı çoklu organ yetmezliğiyle seyreden hiperferritinemik sendrom olduğu ileri sürülmüştür. ${ }^{24}$ Bizim çalışma grubumuzda yoğun bakım veya mekanik ventilasyon ihtiyacı olan hasta olmadığı için sonuçlarımızda literatürden farklı olarak gruplar arasında ferritin düzeylerinde anlamlı bir fark bulmadık.

Çalışmanın kısıtlılıkları tanımlayıcı ve tek merkezli bir çalışma olmasıdır. Ancak örneklem sayısı literatürdeki mevcut çalışmalarla karşılaştırıldığında yeterli durumdadır. Ayrıca literatürde ferritin, fibrinojen ve prokalsitonin gibi inflamatuar belirteçlerin COVID-19 klinik seyrine etkisini inceleyen oldukça az çalışma vardır. Bu konuda mevcut bilgi havuzuna katkıda bulunacağımızı düşünmekteyiz.
Sonuç olarak fibrinojen seviyelerini SARS-CoV-2 pozitif hastalarda daha yüksek olarak saptadık. Ayrıca hastalığın ağırlığı arttıkça fibrinojen seviyelerinin de arttığını saptadık. Ferritin ve prokalsitonin düzeylerinin ise gruplar arasında anlamlı farklılık göstermediğini tespit ettik. Fibrinojen gebelerde COVID-19 klinik durumu ağırlığı ile ilgili bir gösterge olabilir ancak bu bulguyu güçlendirmek için daha büyük örnekleme sahip prospektif, izleme dayalı çalışmalar gerekmektedir.

\section{Etik onay}

Çalışmanın yürütülmesinde Samsun Eğitim ve Araştırma Hastanesi Girişimsel Olmayan Klinik Araştırmalar Etik Kurulunun 13.01.2021 tarih ve 2021/1/16 sayılı etik kurul onayı gözetilmiştir.

\section{Çıkar çatışması beyanı}

Yazarlar arasında veya yazarların herhangi bir kurumla arasında çıkar çatışması yoktur.

\section{Katkı oranı beyanı}

Huri Güvey: Makale metnini yazma, Canan Soyer Çalışkan: Çalışma verilerine ulaşma sisteme girme, Merve Yılmaz: İstatistiksel analizleri yapma, Samettin Çelik: Verilerin değerlendirilmesi ve süpervizyon, Zehra Yılmaz: Verilerin toplanması ve yorumlanması. 
Sakarya Tip Dergisi 2021;11(4):940-946

GÜVEY ve Ark., İnflamatuar Belirteçler ve Gebelerde COVID-19

\section{References}

1. World Health Organization. Director-General's remarks at the media briefing on 2019$n \mathrm{CoV}$ on 11 February 2020. https://www.who.int/dg/speeches/detail/who-director-general-s- remarks-at-the-media-briefing-on-2019-ncov-on-11-february-2020. 2020. p. 2020. (Erişsim tarihi: 29.04.2021)

2. Ramanathan K, Antognini D, Combes A, Paden M, Zakhary B, Ogino M, et al. Clinical features of patients infected with 2019 novel coronavirus in Wuhan, China. Lancet 2020;395(10223):497-506.

3. Schwartz D. The Effects of Pregnancy on Women with COVID-19: Maternal and Infant Outcomes. Clin Infect Dis 2020;71(16):2042-2044.

4. Zaigham M, Andersson O. Maternal and perinatal outcomes with COVID-19: A systematic review of 108 pregnancies. Acta Obstet Gynecol Scand 2020;99(7):823-829.

5. Levi M, Toh CH, Thachil J, Watson HG. Guidelines for the diagnosis and management of disseminated intravascular coagulation. Br J Haematol 2009;145(1):24-33.

6. Di Micco P, Russo V, Carannante N, Imparato M, Cardillo G, Lodigiani C. Prognostic Value of Fibrinogen among COVID-19 Patients Admitted to an Emergency Department: An Italian Cohort Study. J Clin Med 2020;9(12):4134.

7. Lippi $G$, Cervellin G. Procalcitonin for diagnosing and monitoring bacterial infections : for or against? Clin Chem Lab Med 2018;56(8):1193-1195.

8. Kell DB, Pretorius E. Serum ferritin is an important inflammatory disease marker, as it is mainly a leakage product from damaged cells. Metallomics 2014;6(4):748-773.

9. Ruddell RG, Hoang-Le D, Barwood J, Rutherford P, Piva T, Watters D, et al. Ferritin functi-

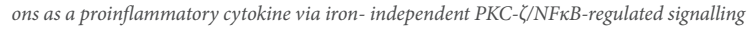
in rat hepatic stellate cells. Hepatology 2010;49(3):887-900.

10. Dahan S, Segal G, Katz I, Hellou T, Tietel M, Bryk G, et al. Ferritin as a Marker of Severity in COVID-19 Patients: A Fatal Correlation. IMAJ 2020;22(8):494-500.

11. Delahoy M, Whitaker M, O'Halloran A, Chai SJ, Kirley PD, Alden N, et al. Characteristics and maternal and birth outcomes of hospitalized pregnant women with laboratory-confirmed COVID-19 - COVID-NET, 13 States, March 1-August 22, 2020. MMWR 2020;69(38):1347-1354.
12. Clinical spectrum of SARS-CoV-2 infection. https://www.covid19treatmentguidelines.nih. gov/overview/clinical-spectrum/ (Erișim tarihi 29.04.2021).

13. Bi X, Su Z, Yan H, Du J, Wang J, Chen L, et al. Prediction of severe illness due to COVID-19 based on an analysis of initial Fibrinogen to Albumin Ratio and Platelet count. Platelets [Internet] 2020;31(5):674-679.

14. Han H, Yang L, Liu R, Liu F, Liu F, Wu KL, et al. Prominent changes in blood coagulation of patients with SARS-CoV-2 infection. Clin Chem Lab Med 2020;58(7):1116-1120.

15. Minasyan H, Flachsbart F. Blood coagulation: a powerful bactericidal mechanism of human innate immunity. Int Rev Immunol [Internet] 2019;38(1):3-17.

16. Delvaeye M, Conway EM. Coagulation and innate immune responses: Can we view them separately? Blood [Internet]. 2009;114(12):2367-2374.

17. Xiang JZ, Cao DY, Yang YYY, Cezmi YY, Gao AAY. Clinical characteristics of 140 patients infected with SARS- CoV-2 in Wuhan, China. Allergy 2020;00:1-12.

18. Guan W, Ni Z, Hu Y, Liang W, Ou C, He J,et al. Clinical Characteristics of Coronavirus Disease 2019 in China. New 2020;382:1708-1720.

19. Lippi G, Plebani M. Procalcitonin in patients with severe coronavirus disease 2019 (COVID-19): A meta-analysis. Clin Chim Acta 2020;505:190-191.

20. Van Berkel M, Kox M, Frenzel T, Pickkers P, Schouten J, Van Berkel M, et al. Biomarkers for antimicrobial stewardship: A reappraisal in COVID-19 times? Crit Care 2020;24(1):1-4.

21. Liu W, Wang Q, Zhang Q, Chen L, Chen J, Zhang B, et al. Coronavirus disease 2019 (COVID-19) during pregnancy: a case series. Preprints 2020;2020020373.

22. Banchini F, Cattaneo GM, Capelli P. Serum ferritin levels in inflammation : a retrospective comparative analysis between COVID-19 and emergency surgical non-COVID-19 patients. World J Emerg Surg 2021;16:9.

23. Cheng L, Li H, Li L, Liu C, Chen H, Li Y. Ferritin in the coronavirus disease 2019 ( COVID-19): A systematic review and meta-analysis. J Clin Lab Anal 2020;34:e23618.

24. Colafrancesco S, Alessandri C, Conti F, Priori R. COVID-19 gone bad: A new character in the spectrum of the hyperferritinemic syndrome? Autoimmun Rev 2020;19:102573. 